\title{
HUBUNGAN ANTARA KREATIVITAS DENGAN PRESTASI BELAJAR SISWA
}

\author{
Dindin Komarudin \\ Fakultas Psikologi UIN Sunan Gunung Djati Bandung, Jl. A.H Nasution No. 105 Bandung \\ email: didinmuorinho@yahoo.co.id
}

\begin{abstract}
Abstrak
Salah satu aspek yang dapat mendorong siswa agar dapat berprestasi dalam pendidikan adalah kreativitas, yaitu suatu proses mental dimana pengalaman masa lalu dikombinasikan kembali seringkali dengan bentuk yang diubah sedemikian rupa sehingga dapat timbul adanya pola-pola baru, bentuk-bentuk baru yang lebih baik yang dapat mengatasi kebutuhan tertentu manusia. (Rogers, 1973). Penelitian ini dilakukan untuk mengetahui hubungan antara kreativitas dengan prestasi belajar. Untuk itu digunakan rancangan penelitian non-experimental design dengan metode korelasional. Kreativitas diukur dengan menggunakan Tes Kreatifitas Verbal dan Figural yang disusun oleh Torrence (Munandar, 1977) dengan skala ordinal dan Prestasi Belajar diukur dengan melihat nilai raport kumulatif para siswa pada akhir semester yang diturunkan kedalam skala ordinal. Karena kedua variabel penelitian tersebut berskala ukur interval, maka pengujian hipotesis yang digunakan adalah rumus korelasi Pearson. Berdasarkan hasil uji signifikansi tersebut, diperoleh $\mathrm{t}_{\text {hitung }}$ sebesar 1,07 . Dengan taraf signifikansi $\alpha=0,05$ serta derajat kebebasan $\left(\mathrm{dk}_{\mathrm{n}-2}\right)=44$ untuk pengujian dua sisi diperoleh harga $\mathrm{t}_{\text {tabel }}$ sebesar 2.02. Kriteria uji yang digunakan adalah tolak $\mathrm{H}_{0}$ apabila $\mathrm{t}_{\text {hitung }}$ sama dengan atau lebih besar dari $t_{\text {tabel. }}$. Karena harga $t_{\text {hitung }}=1,07$ lebih kecil dari pada harga $t_{\text {tabel }}$ sebesar 2,02 pada taraf siginifikansi 0,05 , maka $\mathrm{H}_{0}$ diterima. Dengan demikian dapat dikatakan bahwa tidak terdapat hubungan positif yang signifikan antara kreativitas dengan prestasi belajar.
\end{abstract}

Kata kunci : kreativitas verbal, kreativitas figural, dan prestasi belajar

\section{Abstract}

One of aspects that can encourage students in order to be able to get achievement in education is creativity, i.e., a mental process in which experiences in the past is recombined often with a form changed. This research is done to know the correlation between creativity and study achievement. Related to it, non-experimental with correlation method is used. Creativity is measured by using verbal and figural creativity test composed by Torrence (Munandar, 1977) with ordinal scale study achievement is measured by looking the cumulative value of student reports in the last of semester which is put into the ordinal scale. Because both the scales have interval scale, so the hypothesis test used is the formula of Pearson correlation. Based on the result of significance test, it is gotten that $t_{\text {hitung }}$ is 1,07. With standard of significance $\alpha=0,05$ and $\left(d k_{n-2}\right)=44$ for the test of both sides, it is gotten $t_{\text {tabel }}=2.02$. The criteria test used is repelling $H_{0}$ if $t_{\text {hitung }}$ is the same as or higher than $t_{\text {tabel. }}$. However $t_{\text {hitung }}=1,07$ is not higher than $t_{\text {tabel }}=2,02$ on the standard of significance $=0,05$, therefore $H_{0}$ is accepted. So, it can be said that there is no the significant positive correlation between creativity and study achievement.

Keywords : verbal creativity, figural creativity, and study achievement 


\section{PENDAHULUAN}

Istilah kreativitas atau daya cipta sering digunakan di lingkungan sekolah, perusahaan, ataupun lingkungan lainnya. Pengembangan kreativitas ini diperlukan untuk menghadapi arus era globalisasi. Kreativitas biasanya diartikan sebagai kemampuan untuk mencipta suatu produk baru. Ciptaan itu tidak perlu seluruh produknya harus baru, mungkin saja gabungannya atau kombinasinya, sedangkan unsurunsurnya sudah ada sebelumnya.

Kreativitas dapat pula kita lihat sebagai suatu proses dan mungkin inilah yang lebih penting untuk dilihat terutama dalam situasi pendidikan, kreativitas sebagai suatu proses dari adanya kesenangan akan keterlibatan seseorang terhadap kegiatan kreatif. Dalam situasi pendidikan, proses belajar mengajar merupakan salah satu dari bentuk kegiatannya. Melalui proses belajar mengajar, kreativitas siswa dapat dipupuk dan dikembangkan. Hal inidapat diwujudkan dalam bentuk kegemaran untuk terlibat dalam mencari pengetahuan seperti, membaca buku di perpustakaan, kegiatan di laboratorium, dan lain-lain). keberanian dalam mengemukakan ide maupun pendapat (seperti dalam diskusi dan seminar), aktif dalam kegiatan ekstra kurikuler, dan lain-lain.

Sekolah Menengah Umum atau SMU merupakan sebuah lembaga pendidikan dengan jenjang pendidikan yang setingkat lebih tinggi dari Sekolah Lanjutan Tingkat Pertama. Siswa SLTP pada setiap akhir masa pendidikannya akan memperoleh hasil evaluasi nilai dari hasil belajar mereka selama di SLTP yang dikenal dengan UN atau Ujian Akhir Nasional. Dengan hasil UN ini, setiap siswa dapat memilih sendiri SMU mana yang akan dipilihnya. Besar kecilnya nilai UN akan mempengaruhi diterima atau tidaknya seorang siswa di SMU tersebut. Pada umumnya setiap SMU memiliki standar UN tertentu untuk calon siswa-siswanya, sehingga pada satu sekolah akan diisi oleh siswa-siswa dengan latar belakang UN yang rata-rata hampir sama. Untuk sekolah yang memiliki siswa dengan UN tinggi akan menjadi populer berhubung tingginya prestasiprestasi yang dicapainya. Namun untuk sekolah yang terdiri dari siswa yang memiliki UN rendah biasanya menjadi tidak populer, sebab mereka kurang mampu menunjukkan prestasinya. Berbeda halnya dengan SMK Al Hasan, di SMK ini, siswa-siswanya terdiri atas siswa dengan nilai UN rendah dan siswa dengan nilai UN tinggi. Besar kecilnya nilai UN yang diraih oleh siswa tidak menjadi syarat untuk masuk ke SMK ini. Dalam usianya yang masih muda, SMK ini telah berhasil melahirkan siswa-siswa berprestasi diantaranya seperti juara I dan II lomba pidato bahasa inggris seBandung Raya, juara I dan III lomba mading IKAPI se Jawa Barat, juara umum futsal seBandung Timur, juara III dan Favorit cerdas cermat komputer.

Berdasarkan hasil wawancara peneliti dengan Kepala Sekolah SMK Al Hasan pada hari rabu tanggal 11 november tahun 2008, didapatkan gambaran bahwa kreativitas sangat berhubungan dengan prestasi belajar siswa. Hal ini terlihat dengan adanya diskusi di kelas maupun ketika jam istirahat siswa begitu aktif mengadakan diskusi, banyak bertanya ketika guru menyampaikan materi, kemudian pengunjung di perpustakaan tiap harinya rata-rata $80 \%$, diadakan pertemuan dua minggu sekali antara guru dengan siswa yang sifatnya diskusi tentang pelajaran-pelajaran yang belum dipahami oleh siswa. Wawancara pun dilakukan terhadap 10 siswa kelas 11 dan didapatkan gambaran bahwa kebebasan mereka dalam melakukan sesuatu, diantaranya diskusi, seminar, kegiatan di laboratorium, siswa dapat menentukan jadwal pelajaran sendiri.

Hal ini dapat membuat mereka merasa mampu untuk mengeluarkan segala kemampuannya. Dengan mengembangkan kemampuan kreatifitas mereka dan dibantu oleh guru, mereka dapat merubah suasana yang membosankan menjadi menyenangkan khususnya ketika sedang menghadapi mata pelajaran yang dianggap sulit, seperti matematika, kimia, fisika, dan lain-lain.

Dengan melihat gambaran di atas, maka kreativitas merupakan salah satu upaya pendidik untuk meningkatkan kemampuan siswa, yaitu meningkatkan prestasi belajar. Tinggi rendahnya prestasi belajar yang dicapai oleh setiap siswa akan sangat dipengaruhi oleh kualitas pribadi dari masing-masing siswa. Seperti yang dikemukakan oleh M. Surya (1979), bahwa faktor intelegensi dan non-intelegensi sebagai faktor internal memberikan sumbangan yang besar terhadap prestasi belajar.

Dengan faktor intelegensi, pada umumnya proses-proses pemikiran yang biasanya dilatih di sekolah terbatas pada ingatan dan kemampuan berpikir konvergen. Selain dari 
kemampuan berpikir konvergen ini, terdapat kemampuan berpikir yang disebut kemampuan berpikir divergen. Kemampuan divergen inilah yang menjadi dasar dari kreativitas. Dalam dunia pendidikan kemampuan berpikir kreatif atau kreativitas ini perlu dikembangkan dengan cara meningkatkan kesenangan siswa untuk bersibuk diri secara kreatif, siswa diharapkan dapat meningkatkan wawasan ilmu pengetahuannya sehingga siswa mampu memecahkan tugas-tugas belajarnya secara efektif (Munandar, 1985).

Dari fenomena tersebut, menarik untuk diketahui bagaimana hubungan antara kreatifitas dengan prestasi belajar pada siswa kelas 11 SMK Al Hasan Bandung Tahun Ajaran 2010-2011.

\section{Kreativitas}

Konsep tentang kreativitas sebenarnya relatif masih baru dan mulai dibahas oleh para ahli sejak mulai meningkatnya perhatian terhadap perbedaan individual. Baru setelah perang dunia ke II, masalah kreativitas menjadi pokok bahasan penelitian dan empiris, Guilford (1950) dalam pidatonya sebagai presiden dari APA yang menekankan padaThe appaling neglect dari studi kreativitas dan ia menunjukan pada kebutuhan akan kreativitas di masyarakat dalam suatu pendidikan.

Yang sangat berperan dalam menjelaskan konsep kreativitas adalah pendapat Guilford untuk membedakan antara pemikiran 'konvergen" dan "divergen," pemikiran kreatif atau penalaran logis menuju satu jawaban yang benar, merupakan proses yang mendasari tes intelegensi yang tradisional. Sedangkan pemikiran divergen adalah corak pemikiran yang menghasilkan bermacam-macam gagasan, menurut Guilford merupakan individu yang paling nyata dalam kreativitas (Guilford, 1950).

Menurut Maslow (1959), kreativitas adalah merupakan manifestasi dari integrasi kepribadian dimana tidak ada hambatan dan rintangan dalam alam kesadaran dan ketidaksadaran. Kemampuan untuk regress in the service of the ego. Orang yang demikian dapat berfungsi sepenuhnya, dapat mengaktualisasikan dirinya. Jadi kreativitas tidak hanya bergantung pada intelektual yang tinggi, tapi juga pada perkembangan emosi yang harmonis dan pada kekuatan egonya. Orang yang tegang, bersifat takut-takut, walaupun sebenarnya pandai tetapi tidak tahan terhadap stres maka kurang dapat berfungsi kreativitasnya.begitu pula yang merasa kurang aman, yang merasa kurang mendapatkan afeksi. Hanya individu yang memiliki kekuatan ego dan konsep diri yang sehat yang dapat diharapkan berfungsi penuh.

Dalam bidang lain yang menarik perhatian terhadap penelitian kreativitas adalah berdasarkan konsep bahwa perkembangan kreativitas akan berhubungan dengan mental health. Disini beranggapan bahwa kreativitas dipandang sebagai keseluruhan dari integrasi karakter dari fungsi individu sepenuhnya.

Erat hubungannya dengan mental health teori adalah konsep bahwa kreativitas merupakan kebalikan dari authoritarisme. Stereotype dari kelompok authoritarisme dapat menghambat fingsi-fungsi kreativitas individu. Penelitian yang dilakukan oleh California Psychological Inventory menunjukan bahwa terdapat korelasi antara fleksibilitas (kreativitas) dengan toleransi (Lack of Authoritarism).

Cropley (1967) dalam konsepnya tentang kreativitas mengatakan bahwa berpikir kreatif berarti dapat menggunakan fungsi intelektualnya secara fleksibel dan adaptabel, selalu bersiap sedia merekonstruksi cara berpikirnya. Sebaliknya individu yag rigid selalu terpaku pada hal-hal yang logis dan benar. Mereka tidak menghendaki suatu perubahan yang terlalu cepat dan drastis dalam orientasi intelektualnya, kemungkinan karena memang ia tidak mampu dan terlalu erat berpegang pada sesuatu yang ia ketahui sebagai hal yang benar. Individu demikian berarti kehilangan kreativitasnya.

Sebelum lebih jauh membahas mengenai kreativitas, maka berikut ini dapat dilihat beberapa definisi atau pengertian-pengertian tentang kreativitas yang dikemukakan beberapa ahli. Prof. John E, Arnold dari Stanford University, yang merupakan salah seorang ahli terkemuka dalam bidang ini telah mendefinisikan istilah proses kreativitas sebagai berikut:

Proses mental dimana pengalaman masa lalu dikombinasikan dan dikombinasikan kembali seringkali dengan bentuk yang diubah sedemikian rupa sehingga dapat timbul adanya pola-pola baru, bentuk-bentuk baru yang lebih baik yang dapat mengatasi kebutuhan tertentu manusia". Whiting. (dalam Winardi, 1973). Hilgard (1962) membahas masalah kreativitas sebagai bentuk dari pemikiran terarah (direct 
thingking), dimana dengan pemikiran ini adalah menuju kearah pemecahan masalah. Hal ini berbeda dengan konsepnya tentang pemikiran asosiatif yang merupakan pemikiran yang tidak terkontrol dan tidak terarah yang menuju ke arah lamunan dan mimpi. Sehubungan dengan pemikiran kreatif, Hilgard mendefinisikan sebagai berikut: "the kind of directive thinking, that discover new relationship achieves new solution to problems invent methods or devices produces new artistic object of form". (Hilgard, 1962).

Hulbect (1945) mengatakan bahwa tindakan kreatif memberi pengaruh yang unik dari keseluruhan kepribadian terhadap lingkungannya," creative action, is imposing of ones own whole personality on environment in unique and characteristic way" (Munandar, 1977 ). Untuk lebih jelas pengertian kreativitas, dibawah ini dikemukakan beberapa perumusan yang merupakan simpulan dari beberapa ahli mengenai kreativitas:

Kreativitas adalah kemampuan untuk membuat kombinasi baru berdasarkan data, informasi atau unsur-unsur yang ada. Kreativitas biasanya diartikan sebagai kemampuan untuk mencipta suatu produk baru. Ciptaan itu tidak seluruhnya harus baru mungkin saja gabungannya atau kombinasinya sedangkan unsurunsur lain sudah ada sebelumnya. Yang dimaksud dengan data, informasi dan unsur-unsur yang ada dalam arti sudah ada sebelumnya, atau sudah dikenal sebelumnya adalah semua pengalaman yang diperoleh seseorang selama hidupnya. Disini termasuk segala pengetahuan yang pernah diperolehhnya baik selama di bangku sekolah maupun yang dipelajari dalam keluarga dan dalam masyarakat (Munandar, 1977). Jelaslah makin banyak pengalaman dan pengetahuan yang dimiliki seseorang makin memungkinkan dia memanfaatkan dan menggunakan segala pengalaman dan pengetahuan tersebut untuk bersibuk diri secara kreatif. Gagasan-gagasan yang kreatif, hasil-hasil karya kreatif tidak muncul begitu saja. Untuk dapat menciptakan sesuatu bermakna dibutuhkan persiapan. Masa seorang anak duduk dibangku sekolah termasuk masa persiapan ini karena pendidikan mempersiapkan seseorang agar dapat memecahkan masalah-masalah. Hal ini tidak berarti bahwa makin banyak seseorang memiliki pengalaman dan pengetahuan makin kreatif. Pengalaman dan pengetahuan memungkinkannya untuk mencipta, lebih dari- pada seseorang yang tidak mempunyai banyak pengalaman dan pendidikan. Salah satu hal yang menentukan sejauh mana seseorang kreatif adalah kemampuannya untuk dapat membuat kombinasi baru dari hal-hal yang ada.

Kreativitas (berpikir kreatif atau berpikir divergen) adalah kemampuan berdasarkan data dan informasi yang tersedia untuk menentukan banyak kemungkinan banyak terhadap masalah, dimana penekanannya adalah kuantitas, ketepatgunaan, dan keragaman jawaban. Makin banyak kemungkinan jawaban yang dapat diberikan terhadap suatu masalah makin kreatiflah seseorang. Tentu saja jawaban harus sesuai dengan masalahnya jadi tidak semata-mata banyaknya jawaban yang diberikan yang menentukan kreativitas seeorang, tapi kualitas dan mutu jawabannya (Munandar, 1977).

Jadi secara operasional kreativitas dapat dirumuskan sebagai kemapuan yang mencerminkan kelancaran berpikir (fleksibilitas), orisinilitas dalam berpikir dan kemampuan untuk mengembangkan, memperkaya, memperinci (elaborasi) suatu gagasan. Rhodes (1961) menyatakan bahwa dalam kreativitas terdapat 4 unsur pokok berpikir kreatif atau four $P$ of creativity, yaitu:

Person. Seseorang yang kreatif memiliki ciri-ciri kepribadian tertentu seperti mempunyai rasa ingin tahu yang besar, mempunyai daya imaginasi yang kuat, mempunyai minat yang besar, tekun dan ulet dalam mengerjakan tugas-tugasnya. Process. Seseorang yang senang dan berminat untuk melibatkan diri dalam proses kreatif. Yang dimaksud dengan melibatkan diri secara kreatif adalah kecenderungan untuk selalu melihat dan membentuk kombinasi baru dari unsur-unsur yang diamati dari lingkungan atau dari dalam pkikirannya. Press (dorongan). Yaitu kondisi yang dapat mendorong atau menghambat seseorang untuk bertindak kreatif. Dorongan bisa berasal dari luar atau dari dalam diri (motivasi pribadi). Jika kedua kondisi menunjang akan lebih memungkinkan untuk bertindak kreatif. Produk. Ditinjau dari produk kemampuan berpikir kreatif adalah merupakan kemapuan untuk menghasilkan sesuatu yang baru, baik itu untuk individu yang menciptakannya atau untuk lingkungannya.

Definisi kreativitas dibedakan dalam definisi konsensual dan konseptual. Definisi konseptual menekankan segi produk kreatif yang dinilai derajat kreativitasnya oleh pengamat 
ahli. Amabile (1983) mengemukakan bahwa "suatu produk atau respon seseorang dikatakan kreatif apabila menurut penilaian seorang ahli atau pengamat yang mempunyai kewenangan dalan bidang ini. Dengan demikian kreativitas merupakan suatu produk atau respon yang dinilai kreatif oleh pengamat yang ahli.

Definisi di atas didasari oleh asumsiansumsi sebagai berikut: Produk kreatif atau respon-respon yang dapat diamati merupakan manifestasi puncak kreativitas. Kreativitas adalah sesuatu yang dapat dikenali oleh pengamat luar dan mereka dapat sepakat bahwa sesuatu itu adalah produk kreatif. Kreativitas berbeda derajatnya dan para pengamat dapat sampai pada kesepakaatan bahwa suatu produk lebih kreatif dari yang lain.

Definisi konseptual sering digunakan dalam studi kreativitas dalam lapangan keilmuan dan kesenian, baik menyangkut produk, orang, proses, press maupun lingkungan tempat orang-orang mengembangkan kreativitasnya. Berbeda dengan definisi konsensual, definisi konseptual bertolak dari konsep tertentu tentang kreativitas yang dijabarkan dalam kriteria tentang apa yang disebut kreatif. Meskipun tetap menekankan pada segi produk, definisi ini tidak mengandalkan semata-mata pada konsensus pengamat dalam menilai kreativitas, melainkan didasarkan pada kriteria tertentu.

\section{Prestasi Belajar}

Beberapa ahli berpendapat bahwa belajar adalah suatu proses yang dimulai pada saat individu lahir dan berlangsung terus sampai akhir hayatnya. Dalam belajar terjadi perubahan tingkah laku yang bersifat menetap. Dari proses belajar tersebut akan diperoleh polapola respon baru yang akan memperbaiki polapola tingkah laku secara keseluruhan. Proses belajar pada dasarnya merupakan hal terpenting dari suatu proses pendidikan secara keseluruhan.didalam proses belajar tersebut akan terjadi perubahan tingkah laku yang dirancang secara sengaja dan sadar untuk menuju pada tercapainya suatu tujuan tertentu, yaitu tujuan pendidikan.

Terjadinya suatu proses belajar dapat dipandang sebagai pemuasan kebutuhan artinya belajar merupakan salah satu cara atau bentuk tingkah laku untuk memperoleh pemuasan ke- butuhan tertentu. Witherrington (1959) bahwa belajar terjadi apabila kebutuhan pada individu tidak dapat terpenuhi dengan cara refleks atau kebiasaan, yang berarti bahwa pola-pola tingkah laku yang ada tidak memadai untuk dapat memenuhi kebutuhan individu sehingga perlu dicari cara-cara atau pola-pola tingkah laku yang diperoleh melalui belajar untuk mendapatkan cara-cara baru yang bersifat rasional maupun emosional.

Perubahan tingkah laku terjadi sebagai hasil dari pengalaman. Pengalaman dalam arti kata penghayatan peristiwa secara langsung (misalnya terlalu lama kena sinar matahari menimbulkan kepala terasa pening) dan penghayatan peristiwa secara tidak langsung, artinya melalui suatu perantara orang lain, buku, atau sumber informasi lainnya. Perubahan tingkah laku yang timbul bukan sebagai hasil dari pengalaman tidak termasuk dalam batasan belajar.

Tujuan pendidikan pada umumnya ialah menyediakan lingkungan yang memungkinkan anak didik untuk mengembangkan bakat dan kemampuannya secara optimal, sehingga ia dapat mewujudkan dirinya dan berfungsi sepenuhnya, sesuai dengan kebutuhan pribadinya dan kebutuhan masyarakat (Munandar, 2004)

Dalam proses belajar, pada umumnya individu akan selalu berusaha untuk meraih prestasi yang optimal dan tentunya harus diraih melalui suatu usaha yang optimal dan sarana prasarana yang memadai. Prestasi adalah suatu keberhasilan dalam mencapai tujuan yang diinginkan. Pencapaian nilai-nilai atau angkaangka rapot yang tinggi merupakan salah satu bentuk dari peningkatan prestasi dalam belajar. Pada hakekatnya prestasi belajar adalah hasil belajar yang merupakan perubahan yang terdapat dalam individu yang dimanifestasikan dalam pola tingkah laku.

Winkel (2004: 162) mengatakan: "Prestasi adalah bukti keberhasilan yang telah dicapai. Belajar adalah suatu proses mental yang mengarah kepada penguasaan pengetahuan, kecakapan/skill, kebiasaan atau sikap yang semuanya diperoleh, disimpan dan dilaksanakan sehingga menimbulkan tingkah laku yang progresif dan adaptif. Secara singkat belajar merupakan suatu perubahan dalam tingkah laku yang merupakan hasil dari pengalaman. Tujuan penyelenggaraan sekolah menengah secara khusus untuk memberikan kemampuan minimal bagi lulusan untuk melanjutkan pendidikan dan hidup dalam masyarakat, menyiapkan 
sebagian besar warga Negara menuju masyarakat belajar pada masa yang akan datang, menyiapkan lulusan menjadi anggota masyarakat yang memahami dan menginternalisasi perangkat gagasan dan nilai masyarakat beradab dan cerdas, dan khusus untuk SMA, lulusan atau output memiliki keahlian atau keterampilan tertentu yang dapat dipergunakan untuk memasuki dunia kerja/ dunia usaha.

Sedangkan menurut S. Nasution (1996: 17) prestasi belajar adalah: "Kesempurnaan yang dicapai seseorang dalam berfikir, merasa dan berbuat. Prestasi belajar dikatakan sempurna apabila memenuhi tiga aspek yakni: kognitif, affektif dan psikomotor, sebaliknya dikatakan prestasi kurang memuaskan jika seseorang belum mampu memenuhi target dalam ketiga kriteria tersebut

Proses belajar pada dasarnya merupakan hal terpenting dalam proses pendidikan secara keseluruhan. Dalam proses belajar tersebut akan terjadi perubahan tingkah laku yang diarahkan untuk tercapainya tujuan pendidikan. Proses belajar mengajar dipengaruhi oleh berbagai faktor, baik faktor internal maupun eksternal, sehingga hasil belajar yang dicapai akan banyak tergantung pada faktor-faktor tersebut yang saling berinteraksi satu sama lain. Faktor eksternal adalah faktor di luar diri individu yang mempengaruhi proses belajar, yang dapat digolongkan ke dalam faktor sosial dan faktor non sosial.

Faktor sosial adalah faktor-faktor yang menyangkut hubungan antara manusia yang terjadi didalam berbagai situasi sosial. Termasuk kedalamnya adalah faktor keluarga, sekolah, kelompok sebaya dan masyarakat pada umumnya. Sedangkan faktor non sosial adalah faktor-faktor yang bukan sosial, yang termasuk kedalamnya lingkungan alam dan atau fisik, misalnya kondisi rumah, gedung sekolah, fasilitas belajar, penerangan dan sebagainya.

Adapun faktor internal atau faktor dalam diri individu adalah faktor-faktor yang terdapat dalam diri individu sebagai seorang siswa. Faktor-faktor internal ini adalah faktor fisiologis yaitu setiap ciri-ciri jasmaniah individu dan faktor psikologis yaitu setiap ciri-ciri psikologis individu. Faktor psikologis ini mencakup faktor intelektual baik potensial maupun aktual dan faktor non-intelektual yaitu berupa komponen kepribadian seperti sikap, kebiasan, minat, kebutuhan, motivasi, penyesuaian akademis, dan komponen kepribadian lainnya.
Jika kita bandingkan pengalaman belajar kita dengan pengalaman belajar orang lain dalam suatu peristiwa yang sama, maka akan kita saksikan pengalaman belajar kita berbeda dibandingkan dengan pengalaman belajar orang lain. Belajar merupakan suatu kegiatan subyektif, artinya kita sendiri yang menemukan mau atau tidaknya belajar. Umumnya dapat dikatakan bahwa kita mau bahkan bergairah untuk belajar jika kita tertarik terhadap bahan, masalah atau peristiwa yang dihadapi, kita enggan namun terpaksa walaupun tidak tertarik dengan bahan, masalah atau peristiwa yang dihadapi. Belajar kreatif berhubungan erat dengan penghayatan terhadap pengalaman belajar yang menyenangkan.

Torrance dan Myers (dalam Treffinger, 1980) berpendapat bahwa belajar kreatif adalah menjadi peka atau sadar akan masalah, kekurangan-kekurangan, kesenjangan dalam pengetahuan, unsur-unsur yang tak ada, ketidakharmonisan dan sebagainya, mengumpulkan informasi yang ada, membataskan kesukaran atau mengidentifikasikan unsur yang tidak ada, mencari jawabannya membuat hipotesis, mengubah dan mengujinya, menyempurnakan dan akhirnya mengkomunikasikannya.

Torrance dan Myers (dalam Treffinger, 1980) selanjutnya juga melihat proses belajar kreatif sebagai: "Keterlibatan dengan sesuatu yang berarti. Rasa ingin tahu dan ingin mengetahui dalam kekaguman, ketidaklengkapan, kekacauan, kerumitan, ketidakselarasan, ketidakteraturan dan sebagainya. Kesederhanaan dari struktur atau mendiagnosis suatu kesulitan dengan mensintesiskan informasi yang telah diketahui, membentuk kombinasi baru atau mengidentifikasikan kesenjangan.

Memerinci dan mendivergensi dengan menciptakan alternatif-alternatif baru, kemungkinan-kemungkinan baru dan sebagainya. Mempertimbangkan, menilai, memeriksa dan menguji kemungkinan-kemungkinan. Menyisihkan pemecahan yang tidak berhasil, salah, dan kurang baik. Memilih pemecahan yang paling baik dan membuatnya menarik atau me-nyenangkan secara estetis. Mengkomunikasikan hasil-hasilnya kepada orang lain. Sebagaimana halnya dengan pengalaman belajar yang sangat menyenangkan, pada belajar kreatif kita terlibat secara aktif serta ingin mendalami bahan yang dipelajari.

Hidup dalam suatu masa dimana ilmu pengetahuan berkembang dengan pesatnya untuk digunakan secara konsturktif maupun des- 
truktif, suatu adaptasi kreatif merupakan satusatunya kemungkinan bagi suatu bangsa yang sedang berkembang untuk dapat mengikuti perubahan-perubahan yang terjadi, untuk dapat menghadapi problema-problema yang semakin kompleks.

Oleh karena itu, pengembangan sejak usia dini tentang proses kreatifitas, kondisikondisinya, serta cara yang dapat memupuk, merangsang dan mengembangkannya menjadi sangat penting. Mengapa kreatifitas begitu bermakna dalam hidup? Mengapa kreatifitas perlu dipupuk sejak dini dalam diri anak didik. (Munandar, 2004)

Dengan berkreasi, orang dapat mengaktualisasikan dirinya, dan perwujudan atau aktualisasi diri merupakan kebutuhan pokok pada tingkat tertinggi dalam hidup manusia (Maslow, 1967). Kreatifitas merupakan manifestasi dari individu yang berfungsi sepenuhnya.

Kreatifitas atau berpikir kreatif sebagai kemampuan untuk melihat bermacam-macam kemungkinan penyelesaian terhadap suatu masalah, merupakan bentuk pemikiran yang sampai saat ini masih kurang mendapat perhatian dalam pendidikan (Guilford, 1967). Di sekolah yang terutama dilatih adalah penerimaan pengetahuan, ingatan, dan penalaran.

Bersibuk diri secara kreatif tidak hanya bermanfaat bagi diri pribadi maupun bagi lingkungan, tetapi juga memberikan kepuasan kepada individu. Kreatifitaslah yang memungkinkan manusia dapat meningkatkan kualitas hidupnya.

SMK Al-Hasan memiliki suatu metode yang salah satunya bertujuan untuk menciptakan siswa yang kreatif. Dengan adanya metode ini setiap siswa dihargai secara positif, yang dalam teori Rogers dikenal dengan Uncondition Positif Regard (penghargaan dengan tanpa syarat). Dengan positif regard ini setiap siswa akan dihargai sepenuhnya dan dipandang positif. Dengan berdasar pada metode ini pula, maka untuk menjadi siswa di SMK Al-Hasan, NEM tidak diperhatikan.

Rogers (1973) menyatakan pula bahwa kreativitas adalah suatu potensi yang dimiliki oleh manusia sejak lahir. Adapun bagaimana potensi itu kelak akan ditampilkan keluar adalah tergantung dari suatu kondisi yang dapat memotivasi individu tersebut untuk bertindak kretif. Kreativitas menurut Rogers (1973) merupakan kemampuan untuk membentuk hubungan yang baru dengan lingkungan.
Potensi kreativitas yang dimiliki setiap siswa dapat mengalami hambatan di dalam pengembangannya dengan adanya beberapa kondisi yang kurang dapat memotivasi seseorang untuk bertindak kreatif. Kondisi-kondisi tersebut menurut Rogers (1959) bisa bersifat internal maupun eksternal.

Kondisi internal pertama adalah suatu kondisi yang dikaitkan dengan psychological defensiveness. Bila seorang individu melindungi diri dari pengalamannya atau menolak secara sadar keterlibatannya, maka individu tersebut cenderung menghindar, sehingga dia menjadi apatis. Tetapi pada orang-orang yang terbuka terhadap pengalamannya yaitu bebas dalam menentukan setiap pengalaman yang diterimanya maka pendapat dan pengamatannya akan membentuk tindakan yang lebih kreatif. Artinya individu tersebut memiliki tingkat frigiditas yang rendah, memiliki toleransi terhadap hal-hal yang kurang jelas serta mampu menyadari ketidakjelasan tersebut.

Kondisi internal kedua adalah kondisi yang berhubungan dengan internal locus of evaluation. Kondisi ini menuntut adanya kemampuan mengevaluasi secara internal dalam diri individu yaitu kemampuan menerima hasil kreativitas seseorang tidak ditetukan oleh pujian atau kritikan dari orang lain tetapi oleh diri sendiri.

Kondisi internal ketiga adalah adanya keterbukaan dan keluwesan individu secara spontan dalam bermain dengan ide-ide, warna, bentuk atau hubungan yang ada dalam lingkungannya sehingga meghasilkan sesuatu yang baru. Adapun kondisi eksternal yang mendukung kreativitas menurut Roger adalah kondisi yang mampu memupuk dan mengembangkan kondisi internal, agar terbentuk berpikir kreatif yang konstruktif pada setiap individu.

Dengan adanya kondisi yang mendukung kreativitas seperti yang telah diuraikan di atas maka apabila kedua kondisi mendukung, maka kreativitas individu akan terekspersikan dengan baik atau dengan kata lain kreativitas individu akan meningkat. Sedangkan bila salah satu kondisi terhambat, maka kreativitas individu tidak akan terekpersikan dengan baik dan berarti kerativitas individu menjadi rendah.

Hipotesis penelitian yang diturunkan dari uraian di atas adalah "Terdapat hubungan positif antara kreatifitas dengan prestasi belajar pada siswa kelas 11 SMK Al-Hasan Bandung Tahun Ajaran 2010-2011.” 


\section{METODE PENELITIAN}

Desain penelitian yang akan digunakan dalam penelitian ini adalah rancangan non eksperimental dengan metode korelasional. Populasi dalam penelitian ini adalah semua siswa kelas 11 SMK Al Hasan Bandung Tahun Ajaran 2010-2011 yang berjumlah 46 siswa. Penelitian ini menggunakan metode penelitian populatif, yaitu semua subjek dalam populasi dijadikan sebagai subjek penelitian. Dijadikannya siswa kelas 11 sebagai subjek penelitian adalah karena siswa di kelas ini dianggap lebih mengalami penyesuaian diri dengan kultur sekolah bila dibanding kelas 10 serta masih aktif dan fokus terhadap kegiatan belajar mengajar bila dibanding dengan kelas 13. Untuk mendapatkan data dalam penelitian ini, peneliti menggunakan Tes Kreativitas Verbal dan Figural yang disusun oleh Torrence (Munandar 1977) serta nilai raport yang didapatkan siswa. Karena kedua variabel berskala interval, maka korelasi antara dua variabel dihitung dengan menggunakan perhitungan statistik korelasi Pearson.

\section{HASIL DAN PEMBAHASAN}

\section{Hasil}

Dari hasil perhitungan, diketahui bahwa koefisien korelasi antara kreativitas dengan prestasi belajar adalah sebesar 0,159 dengan $P_{\mathrm{v}}$ sebesar 0,293 pada taraf signifikansi $\alpha=0,05$ dengan arah pengujian dua sisi. Berdasarkan kriteria koefisien korelasi Guillford, indeks korelasi sebesar 0,159 tersebut memiliki arti tingkat korelasi rendah.

\section{Pembahasan}

Hasil pengujian hipotesis menunjukkan bahwa kreativitas memiliki hubungan yang kurang signifikan dengan prestasi belajar. Berdasarkan hasil analisis, diperoleh hasil koefisien korelasi sebesar 0,159. Berdasarkan hasil perhitungan tersebut maka hipotesis yang diajukan dalam penelitian ini ditolak, yaitu tidak terdapat hubungan yang positif antara kreativitas dengan prestasi belajar pada siswa kelas 11 SMK Al-Hasan Bandung Tahun Ajaran 2010-2011. Hasil yang didapatkan tersebut menurut peneliti menunjukkan beberapa hal, diantaranya:
Pertama, Prestasi belajar adalah suatu keberhasilan didalam belajar yang ditunjukkan oleh adanya pencapaian nilai-nilai yang tinggi. Siswa-siswa kelas 11 SMK Al-Hasan Bandung Tahun Ajaran 2010-2011 pada umumnya memiliki prestasi yang sedang, hal tersebut dapat dilihat dari prosentase rata-rata nilai kumulatif raport siswa yang berada pada klasifikasi sedang. Untuk mencapai nilai tinggi tersebut terdapat beberapa faktor, yaitu faktor internal dan faktor eksternal. Salah satu faktor internal yang mendukung prestasi belajar adalah faktor intelegensi. Berdasarkan hasil analisis deskriptif diketahui perbandingan, bahwa $67.4 \%$ siswa yang memiliki tingkat intelegensi sedang memiliki tingkat kreativitas yang sedang, sedangkan $82.6 \%$ siswa yang memiliki tingkat intelegensi sedang memiliki tingkat prestasi belajar yang sedang.

Menurut Naylor (1972; dalam Elma Amalia 2002: 48) yang mengungkapkan bahwa prestasi belajar yang dicapai seorang siswa erat kaitannya dengan tingkat inteligensi yang dimilikinya. Siswa yang memiliki tingkat inteligensi tinggi akan lebih mudah untuk menangkap, mencerna, dan memahami materi pelajaran yang diterimanya.

Masih dalam konteks ini, berdasarkan hasil penelitian Gloyer (1980) diketahui bahwa kreativitas tidak memiliki hubungan yang cukup signifikan dengan intelegensi. Untuk melihat kaitan antara intelegensi dengan kemampuan kreativitas, Gloyer memberikan gambaran sebagai berikut: Individu yang highly intelegency dan moderately intelegency menunjukkan variasi-variasi dalam kemampuan berpikir kreatifnya, yaitu highly creativity, moderately creativity and minimally creativity. Sedangkan Individu yang low intlelegency mungkin termasuk kategori minimally creativity.

Dengan perkataan ini intelegensi dan kreativitas mempunyai hubungan yang rendah dengan kelompok low intlegency sedangkan pada kelompok high dan moderate tidak dijumpai korelasi dengan kreativitas, karena masih memperlihatkan tiga variasi kemungkinan yaitu high, moderate and minimal. Baik Wallch, Kagan maupun Glover (1980), menyatakan bahwa intelegensi dengan kemampuan berpikir kreatif pada dasarnya tidak mempunyai hubungan khusus.

Pokok pikiran penting lainnya yang diungkapkan oleh Guilford (1968) adalah bahwa tes intelegensi hanya menuntut individu untuk 
berpikir konvergen, tema item tes ditujukan untuk mendapatkan satu jawaban lainya yang mungkin lebih baik akan dinilai salah. Dalam hal ini subyek tidak diperkenankan untuk memberikan jawaban yang bersifat orisinal. Lebih lanjut jika akan dilakukan pengukuran mengenai kreativitas maka tes yang digunakan harus berbentuk pemikiran divergen, yaitu tes yang tidak hanya didasarkan untuk memperoleh satu jawaban yang paling tepat melainkan dengan munculnya banyak jawaban.

Berdasarkan data tersebut, maka dapat dipahami mengapa tingkat korelasi antara kreativitas dengan prestasi belajar menjadi rendah. Yaitu, karena prestasi belajar berhubungan erat dengan intelegensi, sedangkan intelegensi tidak berhubungan erat dengan kreativitas.

Kedua, Dari hasil penelitian diketahui bahwa kreativitas siswa kelas 11 SMK Al-Hasan Bandung Tahun Ajaran 2010-2011 berada pada klasifikasi sedang. Hal tersebut menunjukkan bahwa bila dibandingkan dengan siswa seusianya, maka kreativitas siswa SMK Al Hasan Bandung kurang berkembang.

Bila ditelusuri secara lebih mendalam, maka sesuai dengan pendapat Rogers (1959) bahwa faktor-faktor yang dapat menghambat kreativitas individu tergantung pada kondisi internal maupun eksternal. Kondisi internal berhubungan dengan psychogical safety dimana individu diterima sebagai seorang yang sangat berharga serta tidak mempuyai external evaluation, tetapi ada suatu pengertian serta kebebasan psikologis yang menyangkut complete freedom of symbolic expression. Semakin bebasnya pendidikan dari represi, semakin besar pula kreativitas individu.

Beberapa hal yang diduga membuat siswa-siswa SMK Al Hasan Bandung merasa tidak memiliki kenyamanan psikologis antara lain: SMK Al Hasan Bandung menjaring para siswanya tanpa menggunakan nilai UAN, sehingga terdapat perbedaan nilai UAN yang menyolok diantara para siswa. Perbedaan nilai UAN ini membuat beberapa siswa merasa memiliki prestasi yang lebih rendah bila dibanding siswa lainnya.Dari hasil wawancara dengan staff pengajar sekolah tersebut, diperoleh data bahwa mereka mengalami kesulitan dalam menyamakan hasil belajar siswa, terutama karena perbedaan pemahaman yang berbeda. Adanya persaingan yang tidak seimbang ini, menyebabkan siswa menjadi tidak mandiri serta cenderung lebih banyak bergantung pada guru atau orang lain yang memiliki prestasi diatas siswa bersangkutan. Selain itu, kegiatan ekstra kurikuler yang dilakukan seperti diskusi-diskusi, kegiatan membaca di perpustakaan, dll, ternyata tidak lepas dari absensi yang dikeluarkan oleh sekolah. Hal tersebut menunjukkan bahwa kebebasan siswa untuk melakukan kegiatan kreatif belum sepenuhnya atas kemauan sendiri, namun lebih kearah kewajiban untuk mengisi absensi. Padahal Rogers mengemukakan bahwa kreativitas dapat berkembang dalam situasi dimana penilaian atas tingkah laku kreatif harus didasari oleh kebutuhan dirinya sendiri dan bukan atas penilaian orang lain.

Berbagai aturan baku yang dikeluarkan oleh pihak sekolah secara tidak langsung akan membentuk individu yang kaku. Sedangkan salah satu adalah ciri dari kreativitas adalah adanya fleksibilitas berpikir. Seperti yang dikemukakan oleh Cropley (1967) bahwa berpikir kreatif berarti dapat menggunakan fungsi intelektualnya secara fleksibel dan adaptabel, selalu bersiap sedia merekonstruksi cara berpikirnya. Sebaliknya individu yag rigid selalu terpaku pada hal-hal yang logis dan benar. Mereka tidak menghendaki suatu perubahan yang terlalu cepat dan drastis dalam orientasi intelektualnya, kemungkinan karena memang ia tidak mampu dan terlalu erat berpegang pada sesuatu yang ia ketahui sebagai hal yang benar. Individu demikian berarti kehilangan kreativitasnya.

\section{SIMPULAN DAN SARAN}

\section{Simpulan}

Berdasarkan hasil analisis dan pembahasan tentang hubungan antarakreativitas dengan prestasi belajar pada siswa kelas 11 SMK Al-Hasan Bandung Tahun ajaran 2010-2011 dapat ditarik simpulan bahwa tidak terdapat hubungan positif yang signifikan antara kreativitas dengan prestasi belajar pada siswa kelas 11 SMK Al-Hasan Bandung.

\section{Saran}

Berdasarkan hasil penelitian yang telah dilakukan, dengan memperhatikan keterbatasan-keterbatasan dalam penelitian ini, peneliti mengajukan saran-saran agar dapat dijadikan bahan pertimbangan sebagai berikut: 
Bagi lembaga, dikarenakan hasil penelitian menunjukkan bahwa tingkat kreativitas kurang memiliki hubungan dengan prestasi belajar, maka peneliti memberikan saran bagi lembaga untuk mengadakan kegiatan ekstrakurikuler yang berorientasi pada peningkatan prestasi belajar disesuaikan dengan minat yang dimilikinya.

Saran lain bagi lembaga, karena dukungan sosial diduga menjadi salah satu faktor eksternal yang menjadi penunjang bagi tingginya tingkat prestasi belajar, maka disarankan kepada lembaga untuk mengadakan kegiatan diskusi sebagai media untuk memotivasi serta menginspirasi setiap siswa sehingga diharapkan prestasinya semakin meningkat.

Untuk penelitian selanjutnya, karena hubungan antara kreativitas dan prestasi belajar kurang signifikan maka peneliti memberi masukkan kepada peneliti lain untuk mencari variabel lain yang diduga memiliki hubungan yang lebih signifikan dengan prestasi belajar.

\section{DAFTAR PUSTAKA}

Al-Rasyid, H. (1994). Statistika Sosial. Bandung: PPS Universitas Padjajaran

Arikunto, Suharsimi. Prof. Dr. (2000). Manajemen Penelitian. Jakarta: Rineka Cipta

Anderson, J.R.. (1980). Cognitive psychology and its implication, W.H. Freeman, San Francisco

Azwar, Saefuddin. (2004). Penyusunan Skala Psikologi. Yogyakarta: Pustaka Pelajar Offset

Amable.(1983).Creativity In Context. Westview Pres

Champion, D.J. (1981). Basic Statistic For Social Research. New York: Library of Congress Cataloging In Publikcatio

Chaplin, J.P. (1997). Dictionary Psuchology. New York: Dell Pub, Co Inc.

Cropley, A.J. (1967). Creativity, Edited by P.E Vernon.Penguin Education

Freidenberg, L. (1995). Psychological Testing Design, Analisis, and Use. Massachussest: A Simon \& Schuster Company

Guilford, J.P. (1950). Intelegence, Creativity and Their Educational Implication. California: Robert R. Knapp

,(1967).Statistic In Psychology \& Education.Elexmedia Komputido

Gary. (1980). Cristian Counseling : A Comprehensif Guide.Word Publishing
Hilgard, E.R. (1962). Introduction to Psychology, $3{ }^{\text {th }}$ Edition. New York: Brace and Wardl, Inc.

Hulbect \&Kinnon.(1945). "Title $V$ " bimbingan dan konseling.New York: Dell Pub, Co Inc.

Hurlock.E. (1978).Child Development, $6^{\text {th }}$ Edition. New York: Mc Graw Hill Kogakusha Ltd

Lowenfeld, V. et.all.(1975). Creative and Mental Growth, $6^{\text {th }}$ Edition. New York: Mac Millan Publishing Co. Inc.

M. Surya. (1979). Disertasi, Pengaruh Faktor Non Intelektual terhadap Gejala Berprestasi Kurang.Yogyakarta

Munandar, S.C.U. (1992). Mengembangkan bakat dan kreatifitas anak sekolah. Jakarta: Gramedia , (2004). Pengembangan Kreatifitas Anak Berbakat. Jakarta: Rineka Cipta , (1988). Laporan penelitian Standarisasi tes Kreativitas Verbal, Fakultas psikologi Universitas Indonesia Jurusan Psikologi Pendidikan , (1977). Creativity and Education. Direktorat Jendral Perguruan Tinggi Departemen Pendidikan dan Kebudayaan ,(1985).Potensi Kreativitas Anak Berbakat.Fakultas Psikologi Universitas Indonesia Jurusan Psikologi Pendidikan

Moslow.(1959).Growth Psychology Model of healthy personality. New York.

Nazir, M. (1988). Metode Penelitian. Jakarta: Ghalia Indonesia

Nasution,S (1996). Psikologi Pendidikan. Jakarta: PT.Bumi Aksara

Renzulli, J.S. (1977). The Enrichment Triad Model: A Guide for Developing Defensible Programs for the Gifted and Talented. Connecticut: Creative Learning Pr

Riduan Drs. M.B.A.. (2005). Skala Pengukuran Variabel-variabel Penelitian. Bandung: Alfabeta

Rogers C.R., (1959). Creativity, ch.13, Selected Reading, Edited by P.E. Vernon, Penguin Education

Rhodes (1961).A Decentered Theory of Governence. New York

Sarwono, Sarlito Wirawan Prof. Dr. (2002). Teori-teori Psikologi Sosial. Jakarta: PT. Raja Grafindo Persada

Siegel, S. (1992). Statistik Nonparametrik Untuk Ilmu-Ilmu Sosial. Jakarta: PT Gramedia Pustaka Utama 
Syamsudin, A.(1981). Psikologi Pendidikan. Bandung: Remaja Rosda karya

Sudjana, (2001). Metoda Statistika. Bandung: PT. Tarsito

Surya, M. (1979). Psikologi pembelajaran dan Pengajaran. Bandung: Surya pustaka

Supriadi, D. (1994). Kreatifitas, Kebudayaan dan Perkembangan Iptek. Bandung: Alfabeta

Schaeffer, C. (1971). A Common Word Between Us and You. Penguin Education

Thalib, M. (2001). Seni dan Sikap Islami Mendidik Anak. Bandung: IBS

Treffinger. (1980). Membiasakan Belajar Nya- man dan Menyenangkan. Jakarta: Grasindo

Wallach, M.A. (1973). Creativity, ch. 19, Selected reading, Edited by P.E. Vernon. Penguin Education

Wingkel, W.S. (2004). Psikologi Pengajaran. Jakarta: Grasindo

Winardi. (1973). Kreatifitas dan tehnik-tehnik pemikiran kreatif. Jakarta: Citra Aditya Bakti

Williams. (1975). Culture And Sociaty. Elexmedia Komputindo

Witherrington. (1959). Education Pschological. Penguin Educational 